CLINICAL STUDY

\title{
Novel inactivating mutations in the GH secretagogue receptor gene in patients with constitutional delay of growth and puberty
}

Patricia N Pugliese-Pires ${ }^{1}$, Jean-Philippe Fortin ${ }^{2}$, Thais Arthur ${ }^{3}$, Ana Claudia Latronico ${ }^{1}$, Berenice B Mendonca ${ }^{1}$, Sandra Mara F Villares ${ }^{3}$, Ivo J P Arnhold ${ }^{1}$, Alan S Kopin ${ }^{2}$ and Alexander A L Jorge ${ }^{1,4}$

${ }^{1}$ Unidade de Endocrinologia do Desenvolvimento, Laboratorio de Hormonios e Genética Molecular (LIM/42), Disciplina de Endocrinologia da Faculdade de Medicina da Universidade de Sao Paulo (FMUSP), Sao Paulo 05403-000, Brazil, ${ }^{2}$ Molecular Cardiology Research Institute, Molecular Pharmacology Research Center, Tufts Medical Center, Boston, Massachusetts 02111, USA, ${ }^{3}$ Laboratorio de Nutricao Humana e Doencas Metabolicas (LIM/25) do Hospital das Clinicas da Faculdade de Medicina da Universidade de Sao Paulo (FMUSP), Sao Paulo 01246-903, Brazil and ${ }^{4}$ Unidade de EndocrinologiaGenetica (LIM/25) do Hospital das Clinicas, Disciplina de Endocrinologia da Faculdade de Medicina da Universidade de Sao Paulo (FMUSP), Sao Paulo 01246-903, Brazil

(Correspondence should be addressed to A A L Jorge who is now at Laboratorio de Hormonios, Hospital das Clinicas, Av Dr Eneas de Carvalho Aguiar 155 PAMB, 2 andar Bloco 6,05403-900 São Paulo, Brazil; Email: alexj@usp.br)

\begin{abstract}
Background: A limited number of mutations in the GH secretagogue receptor gene (GHSR) have been described in patients with short stature.

Objective: To analyze GHSR in idiopathic short stature (ISS) children including a subgroup of constitutional delay of growth and puberty (CDGP) patients.

Subjects and methods: The GHSR coding region was directly sequenced in 96 independent patients with ISS, 31 of them with CDGP, in 150 adults, and in 197 children with normal stature. The pharmacological consequences of GHSR non-synonymous variations were established using in vitro cell-based assays.

Results: Five different heterozygous point variations in GHSR were identified (c. -6 G $>$ C, c.251G $>$ T (p.Ser84Ile), c.505G > A (p.Ala169Thr), c.545 T >C (p.Val182Ala), and c.1072G > A (p.Ala358Thr)), all in patients with CDGP. Neither these allelic variants nor any other mutations were found in 694 alleles from controls. Functional studies revealed that two of these variations (p.Ser84Ile and p.Val182Ala) result in a decrease in basal activity that was in part explained by a reduction in cell surface expression. The p.Ser84Ile mutation was also associated with a defect in ghrelin potency. These mutations were identified in two female patients with CDGP (at the age of 13 years, their height SDS were -2.4 and -2.3$)$. Both patients had normal progression of puberty and reached normal adult height (height SDS of -0.7 and -1.4 ) without treatment.

Conclusion: This is the first report of GHSR mutations in patients with CDGP. Our data raise the intriguing possibility that abnormalities in ghrelin receptor function may influence the phenotype of individuals with CDGP.
\end{abstract}

European Journal of Endocrinology 165 233-241

\section{Introduction}

The GH secretagogue receptor (GHSR, OMIM *601898) is a member of the $\mathrm{G}$ protein-coupled receptor (GPCR) superfamily characterized by a seven transmembrane domain structure. There are two isoforms of GHSR: GHSR1a, which is active, and GHSR $1 b$, which is truncated and has no known biological activity (1). Our manuscript is focused on GHSR 1a that will subsequently be referred to as 'GHSR'. This receptor is mainly expressed in the hypothalamus and pituitary (1) and is characterized by a high level of constitutive activity (2). Ghrelin is the endogenous ligand of the GHSR and it is primarily secreted by gastric cells (3). Ghrelin has recently emerged as a pleiotropic neuroendocrine modulator involved in a wide spectrum of biological functions. Through interaction with GHSR1a, ghrelin stimulates GH secretion and has a potent orexigenic effect (4). Two major forms of ghrelin have been demonstrated in the circulation: unacylatedghrelin, which is the main circulating form, and acylghrelin, which is the active form generated by octanoyl incorporation at Ser3, a process mediated by ghrelin $O$-acyltransferase $(5,6)$. This acylation is essential for binding to the GHSR $1 \mathrm{a}$ and for most recognized endocrine actions of ghrelin.

Recently, mutations in the GHSR have been implicated in the etiology of short stature in humans (7-9). Pantel et al. (7) described the missense mutation p.Ala204Glu in the second extracellular loop of the GHSR1a in two 
unrelated families from Morocco. In the first family, the defect was associated with idiopathic short stature (ISS) and in the second family with isolated GH deficiency (GHD). Wang et al. (9) described this same mutation in an obese child. In addition, this group reported another GHSR mutation (p.Phe279Leu) in a boy with ISS as well as in his obese, short mother (9). These first reports suggest that GHSR inactivating mutations may cause short stature and impairment of GH secretion with variable severity and penetrance (7). In 2009, Pantel et al. (8) reported an isolated GHD patient with delayed puberty who was compound heterozygous for two GHSR mutations (p.Trp2X and p.Arg237Trp). Interestingly, the patient's father, who was heterozygous for the nonsense mutation, also had delayed puberty (8). More recently, a Japanese group described four novel heterozygous GHSR mutations (p. Gln36del, p.Pro108Leu, p.Cys173Arg, and p.Asp246Ala) in a group of patients with GHD or ISS (10). Unfortunately, no clinical and laboratory data from these patients were given. All described GHSR missense mutations markedly decreased the constitutive activity of the receptor, but some of these mutations preserved its ability to respond to ghrelin $(7,8,11)$, suggesting the importance of GHSR basal activity for growth (12). In addition, two recent large genome-wide association studies demonstrated a strong association between GHSR loci (3q26.3) and height determination $(13,14)$.

The objective of this study was to investigate the presence of GHSR mutations in a group of ISS patients including a subgroup of patients with constitutional delay of growth and puberty (CDGP).

\section{Patients and methods}

\section{Subjects}

This study was approved by the local ethics committee, and the patients or guardians gave their written informed consent. Subjects in this study included 96 independent Brazilian patients with ISS ( 64 males), who fulfilled the following diagnostic criteria: proportional postnatal short stature, height more than 2.5 SDS below the normal mean height for age and sex (15), unremarkable medical history, and absence of abnormal findings on clinical examination or in laboratory tests that could account for short stature (16). Routine laboratory tests included blood cell count, erythrocyte sedimentation rate, electrolytes, albumin levels, kidney and liver function tests, karyotype (in all female patients), celiac disease screening, and free thyroxine and TSH levels. All children had adequate nutritional status, as assessed by interviews with parents or guardians, showed absence of signs of malnutrition, and satisfied normal laboratory parameters. All patients had normal GH secretion as assessed by GH peak after provocative testing with clonidine or insulin (17).
A total of 83 ISS patients $(88 \%)$ had started puberty prior to the initiation of the genetic studies. According to the age of puberty onset, 31 patients ( 24 males) were subcategorized as presenting with CDGP. The diagnosis of CDGP was based on lack of breast development (Tanner stage 2) by the age of 13 years in girls and testicular volume $<4.0 \mathrm{ml}$ by the age of 14 years in boys, absence of other identifiable causes of delayed puberty, delayed bone age (BA), as well as spontaneous and complete achievement of pubertal development during follow-up (18). The complete pubertal development was established by regular menses in female and normal adult testosterone levels in male CDGP patients.

We also studied as a control group 150 adults $(45 \%$ males) with normal stature (height SDS of $0.3 \pm 1.1$ ) and 197 children (64\% males) without growth impairment (mean age of $10.7 \pm 1.5$, height SDS of $1.0 \pm 1.0$ ) with the same ethnic background.

\section{Hormonal studies}

GH was measured by immunofluorometric assay (AutoDELFIA, PerkinElmer, Waltham, MA, USA) with MABs. The cutoff levels used to rule out GHD diagnosis after stimulation test were peak $\mathrm{GH}$ levels $>3.3 \mu \mathrm{g} / \mathrm{l}$ (17). IGF1 was measured by chemiluminescence assays (IMMULITE, Diagnostic Products Corporation - DPC, Los Angeles, CA, USA) and expressed as SDS for age and sex according to reference values provided by the assay kit. Active ghrelin (acylated ghrelin) levels were measured using a commercial ELISA kit (Millipore, St Charles, MO, USA). Blood samples were collected from a forearm vein in the morning after overnight fasting and again 60 min after intake of a high carbohydrate meal. Whole blood samples were collected in polypropylene tubes and a dipeptidyl peptidase IV inhibitor (Millipore) at a final concentration of $100 \mu \mathrm{M}$ was immediately added. The clotted blood was then centrifuged for $15 \mathrm{~min}$ at $4 \pm 2{ }^{\circ} \mathrm{C}$, plasma was separated and acidified by addition of $\mathrm{HCl}$ to a final concentration of $0.05 \mathrm{M}$, and stored at $-80^{\circ} \mathrm{C}$ until being assayed.

\section{Molecular studies}

Genomic DNA was extracted from peripheral blood leucocytes, and the entire coding region as well as the exon-intron boundaries of GHSR (GenBank accession number NM_198407.2) was PCR amplified in all patients and control group. The GHSR proximal promoter region (1 kb) (19) was also amplified in patients if GHSR allelic variants in the coding region were identified. Primer sequences and amplification protocols will be sent on request. PCR products were bidirectionally sequenced with the dideoxy chaintermination method using a dye terminator kit and analyzed in an ABI Prism 3100 automated sequencer (Applied Biosystems, Foster City, CA, USA). 


\section{In silico prediction of mutation effects}

To identify the potential effects of sequence variants identified in GHSR on splice and protein function or structure, the wild-type (WT) and variant sequences were submitted to Splice Site Prediction by Neural Network (http://www.fruitfly.org/seq_tools/splice.html) (20), SpliceView (http://zeus2.itb.cnr.it/ webgene/ wwwspliceview_ex.html) (21), and a new version of the PolyPhen method (http://genetics.bwh.harvard. edu/pph) (22).

\section{Functional studies}

Materials Ghrelin was purchased from Bachem (Bubendorf, Switzerland). Cell culture media, fetal bovine serum, and lipofectamine reagent were obtained from Invitrogen. Peroxidase-conjugated, anti-hemagglutinin (HA) MAB (3F10) and BM-blue, a peroxidase substrate, were purchased from Roche Applied Science. The plasmid encoding the serum response element (SRE) luciferase reporter gene has been described previously (23).

Construction of human GHSR plasmids The constructs encoding the untagged and HA-tagged WT human GHSR cDNA (isoform 1a) were reported previously (11). Missense mutations were introduced into both template cDNAs (i.e. untagged and HA-tagged receptors) using oligonucleotide-directed site-specific mutagenesis as described previously $(24,25)$. For each mutant, the presence of the indicated amino acid change was confirmed by sequence analysis of the full protein coding region of each construct.

Cell culture Human embryonic kidney (HEK) 293 cells were grown in DMEM (Invitrogen) supplemented with $10 \%$ fetal bovine serum, $100 \mathrm{U} / \mathrm{ml}$ penicillin $\mathrm{G}$, and $100 \mu \mathrm{g} / \mathrm{ml}$ streptomycin. The cells were maintained at $37{ }^{\circ} \mathrm{C}$ in a humidified environment containing $5 \% \mathrm{CO}_{2}$.

Luciferase reporter gene assay Receptor-mediated signaling was assessed using a luciferase assay as described previously $(11,23,26)$. In brief, HEK293 cells were plated at a density of 1000-2000 cells/well onto clear-bottom, white 96-well plates and grown for 2 days to $\sim 80 \%$ confluency. Cells were then transiently transfected using LipofectamineR reagent (Invitrogen) with cDNAs encoding i) a WT or mutant GHSR1a (or an empty expression vector), $2 \mathrm{ng} /$ well, ii) a serumresponsive element-luciferase reporter gene ( $\mathrm{SRE}_{5 \mathrm{x}}$-luc), $30 \mathrm{ng} /$ well, and iii) $\beta$-galactosidase, $5 \mathrm{ng} /$ well, to enable correction of interwell variability. After $24 \mathrm{~h}$ of transfection, cells were stimulated for $4 \mathrm{~h}$ with ghrelin diluted in serum-free medium. Ligand potencies were determined by stimulating receptor-expressing cells with increasing concentrations of ghrelin. The medium was gently aspirated following ligand treatment and luciferase activity was measured using SteadyliteR reagent (PerkinElmer, Boston, MA, USA). A $\beta$-galactosidase assay was then performed after adding the enzyme substrate, 2 -nitrophenyl $\beta$-D-galactopyranoside. Following incubation at $37^{\circ} \mathrm{C}$ for $30-60 \mathrm{~min}$, substrate cleavage was quantified by measurement of optical density at $420 \mathrm{~nm}$ using a SpectraMaxR microplate reader (Molecular Devices, Sunnyvale, CA, USA). Corresponding values were used to normalize the luciferase data.

Assessment of receptor expression using ELISA The expression levels of the GHSR variants were determined using a procedure described by Fortin et al. (27). In brief, HEK293 cells grown in 96-well plates were transiently transfected with a plasmid encoding either an HA-tagged WT or mutant ghrelin receptor, $2 \mathrm{ng} /$ well. After $48 \mathrm{~h}$ of transfection, the cells were washed once with PBS, $\mathrm{pH} 7.4$, and fixed with 4\% paraformaldehyde in PBS for $10 \mathrm{~min}$ at room temperature. After washing with PBS/100 mM glycine, the cells were incubated for $30 \mathrm{~min}$ in blocking solution (PBS/20\% bovine serum). An HRP-conjugated MAB (Roche; clone 3F10) directed against the HA-epitope was then added to the cells (1:500 dilution in blocking solution). After $1 \mathrm{~h}$, the cells were washed five times with PBS, and BM-blue (3,3',5,5'-tetramethylbenzidine, Roche) solution $(50 \mu \mathrm{l} /$ well $)$ was added. After incubation for $30 \mathrm{~min}$ at room temperature, conversion of this substrate by antibody-linked HRP was terminated by adding $2.0 \mathrm{M}$ sulfuric acid $(50 \mu \mathrm{l} /$ well $)$. Converted substrate (which correlates with the amount of receptor) was assessed by measuring light absorbance at $450 \mathrm{~nm}$ using a SpectraMaxmicroplate reader (Molecular Devices).

Data analysis GraphPad Prism software version 5.0 (GraphPad, San Diego, CA, USA) was used for non-linear curve fitting of receptor signaling and for calculation of half-maximal effective concentrations ( $\mathrm{EC}_{50}$ values). Each $\mathrm{EC}_{50}$ value (expressed as a molar concentration) was transformed to a $\mathrm{pEC}_{50}$ value; $\mathrm{pEC}_{50}=-\log \left(\mathrm{EC}_{50}\right)$. The mean $\mathrm{pEC}_{50}$ values \pm s.E.M. are shown. The $\mathrm{pEC}_{50}$ and surface expression values for each of the mutants were compared with the corresponding control values at the WT receptor using one-way ANOVA followed by Dunnett's post-test (GraphPad INSTAT software).

\section{Statistical analysis}

Differences between groups were tested by $t$-test or Kruskal-Wallis and $\chi^{2}$ or Fisher exact test, as appropriate. Statistical analyses were performed using the SIGMA stat statistical software package (Windows version 3.5; Systat Software, Inc., Erkrath, Germany). 
Table 1 Clinical characteristics of patients with ISS with or without CDGP selected for the study.

\begin{tabular}{lccc}
\hline & \multicolumn{3}{c}{ Idiopathic short stature (ISS) } \\
\cline { 2 - 4 } & CDGP & Non-CDGP & Total \\
\hline Number of patients & 31 & 65 & 96 \\
Males (\%) & 77 & 61 & 67 \\
Target height SDS & $-1.2 \pm 0.6$ & $-1.3 \pm 0.6$ & $-1.3 \pm 0.6$ \\
Family history of SS (\%) & 52 & 49 & 50 \\
Data on first evaluation & & & \\
$\quad$ Chronological age (years) & $13.5 \pm 2.6^{*}$ & $9.4 \pm 3.6$ & $10.7 \pm 3.8$ \\
Bone age (years) & $10.7 \pm 2.7^{\star}$ & $7.2 \pm 3.7$ & $8.3 \pm 3.7$ \\
Bone age delay (years) & $3.1 \pm 1.1^{\star}$ & $2.3 \pm 1.2$ & $2.6 \pm 1.3$ \\
Height SDS & $-3.1 \pm 0.9^{\star}$ & $-2.7 \pm 0.8$ & $-2.8 \pm 0.9$ \\
BMI SDS & $-1.7 \pm 1.5^{\star}$ & $-0.6 \pm 1.1$ & $-1.0 \pm 1.4$ \\
IGF1 SDS & $-1.6 \pm 1.5^{\star}$ & $-0.8 \pm 0.9$ & $-1.0 \pm 1.2$ \\
Age at start of puberty & & & \\
Female & $13.5 \pm 0.6^{\star}$ & $11.1 \pm 1.2$ & $11.7 \pm 1.5$ \\
Male & $15.3 \pm 1.5^{*}$ & $12.7 \pm 1.0$ & $13.8 \pm 1.8$ \\
\hline
\end{tabular}

SS, short stature; ${ }^{*} P<0.05$ in comparison with non-CDGP group.

aHeight SDS $<-2.0$ in any one of the parents.

${ }^{\mathrm{b} B r e a s t}$ development (Tanner stage 2 ) in girls and testicular volume $>4.0 \mathrm{ml}$ in boys.

\section{Results}

\section{Patients' characteristics}

Clinical characteristics of the patients are shown in Table 1 . The cohort was characterized by a male predominance, especially in the CDGP group. At the first evaluation for short stature, patients from the CDGP group were older; had shorter height, lower body mass index (BMI) SDS, and lower IGF1 levels; and had more marked delayed BA when compared to patients with normal puberty.

\section{Molecular results}

In ISS patients, five different heterozygous variations in GHSR were identified, all of them in patients with CDGP (three males and two females). Of the five variations, one is located in the $5^{\prime}$-UTR, 6 bp prior to the initiation codon (c. $-6 \mathrm{G}>\mathrm{C}$ ). The other four variations (p.Ser84Ile (c.251G $>$ T), p.Ala169Thr (c.505G >A), p.Val182Ala (c.545 T>C), and p.Ala358Thr (c.1072G $>$ A)) are missense and all of them but p.Ala358Thr predict amino acid changes in highly conserved residues in GHSR. The protein location of the amino acid substitutions is indicated in Fig. 1. No additional variations were identified in the GHSR promoter region in these patients. In silico analysis did not predict changes in the physiological acceptor or donor GHSR splice sites by these allelic variants; in contrast, analysis by PolyPhen (22) suggested that p.Ala169Thr and p.Ala358Thr are benign, whereas p.S84I and p.Val182Ala are predicted to be probably and possibly damaging respectively. All the missense variations were selected for in vitro functional evaluation.
These allelic variants were not found in 694 alleles from controls (adults and normal height children). In addition, no other mutations were identified in the entire GHSR coding sequence in the normal height children (197 individuals sequenced). Notably, the frequency of mutation observed in the CDGP group was higher than that expected by chance in contrast with ISS children $(P=0.003)$ and control children $(P<0.001)$.

\section{Functional studies}

The Ser84Ile GHSR missense mutation alters ghrelin potency Ghrelin failed to increase signaling activity in HEK293 cells transfected with the empty plasmid pcDNA1 (Fig. 2), suggesting absence of an endogenous GHSR. In contrast, in cells expressing recombinant GHSR variants, stimulation with ghrelin triggered a concentration-dependent increase in receptor-mediated signaling. Agonist potency was comparable at the WT, Val182Ala, Ala169Thr, and Ala358Thr receptors (Fig. 2 and Table 2). In contrast, the Ser84Ile variant displayed a significant reduction in ghrelin potency/efficacy.

The Ser84Ile and Val182Ala mutations show decreased basal activity that correlates with reduced cell surface expression Consistent with previous studies using an SRE-luciferase reporter gene assay $(2,11)$, the WT-GHSR exhibited a high level of constitutive activity (i.e. signals in the absence of agonist). The Val182Ala variant showed $\sim 50 \%$ reduction in basal activity relative to WT. Trace, if any, residual basal activity was observed for the Ser84Ile mutant. In contrast, the Ala169Thr and Ala358Thr had a basal activity level comparable to the WT GHSR (Fig. 2 and Table 2). In parallel experiments, cell surface expression levels of variant receptors were determined by ELISA using HA-tagged versions of the WT and mutant GHSR isoforms (Fig. 3

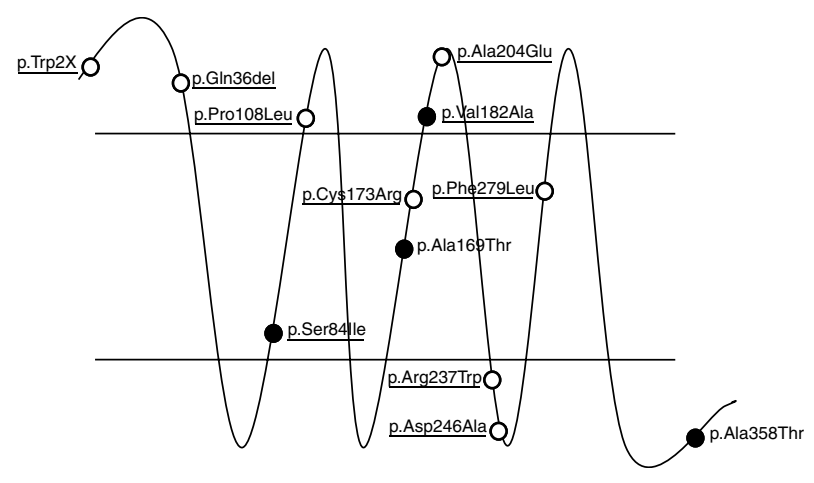

Figure 1 Schematic representation of GHSR and the location of missense variations within the receptor protein. The black circles indicate the variants described in this study. The white circles indicate the mutations already described in the literature. The underlined are mutations with proven functional impairment. 


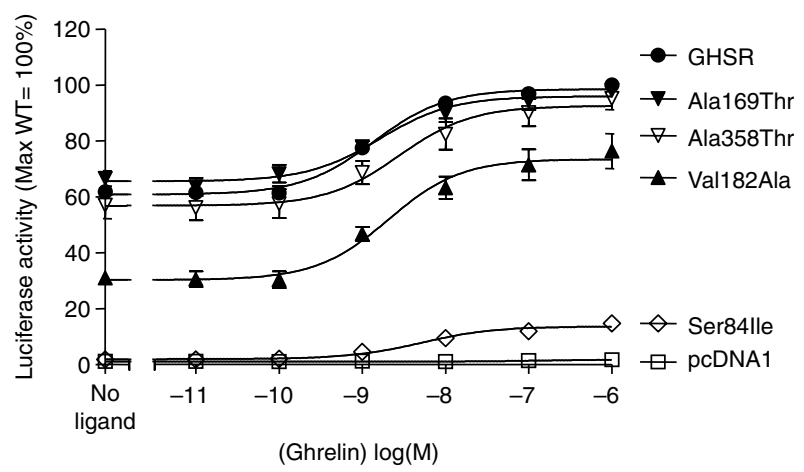

Figure 2 Selected GHSR variants show altered basal receptor activity and/or ghrelin potency. HEK293 cells were transiently transfected with a receptor-encoding cDNA, together with a SRELuc reporter gene construct. After $24 \mathrm{~h}$ of transfection, cells were stimulated for $4 \mathrm{~h}$ with media containing either no peptide (basal) or increasing concentrations of ghrelin. Following stimulation, luciferase activity was quantified as described in Patients and methods section. All activity values were normalized relative to the ghrelinstimulated maximum at the wild-type GHSR. Data represent the mean \pm S.E.M. from at least three independent experiments, each performed in triplicate.

and Table 2). Both tagged and untagged WT receptors showed comparable pharmacological properties (data not shown). These studies revealed that receptors with reduced basal signaling (Val182Ala and Ser84Ile) were also expressed at a significantly lower density relative to the WT GHSR (100\%). Consistent with the major loss of signaling observed with the Ser84Ile variant, this receptor also displayed very poor cell surface expression. The Val182Ala mutant showed an intermediate level of basal activity and receptor expression. Pharmacological abnormalities (i.e. decreased basal activity and/or potency) of the Val182Ala and Ser84Ile were detected for both tagged and untagged receptors (data not shown). In contrast, each of the GHSR variants with normal basal activity (Ala169Thr and Ala358Thr) showed surface expression comparable to WT.

\section{Phenotype/genotype relationships}

Patient with p.Ser84IIe mutation The mutation p.Ser84Ile was identified in a female patient (patient 1) with CDGP. Clinical and laboratory data are shown in Table 3. At her first appointment at 12.8 years, she had short stature with delayed BA and low BMI (height $\mathrm{SDS}=-2.4, \mathrm{BA}=11$ years, and BMI SDS $=-2.6$ ). Her hormonal evaluation showed reduced IGF1 and IGFBP3 levels but a normal GH response to the clonidine test. She started puberty just after this first visit at 13 years and had normal pubertal development with menarche at 16 years. She achieved a normal final height of $157.6 \mathrm{~cm}$ $(-0.7$ S.D.) without GH treatment (her target height was $158.1(-0.7$ S.D. $))$ but maintained a low BMI of $18.4 \mathrm{~kg} / \mathrm{m}^{2}$. At adult age, her IGF1 levels increased to normal, but her IGFBP3 levels remained low.
Gonadotropins and estradiol levels were at prepubertal range at the first evaluation and reached adequate levels by the end of puberty (Table 3). She had normal levels of basal ghrelin and adequate suppression after the highcarbohydrate breakfast meal. No abnormalities in glucose homeostasis were observed. At the age of 21 years, she gave birth to a healthy female child. The patient's mother and her daughter had a normal GHSR genotype. In contrast, her two siblings who had normal stature and puberty were also heterozygous for the same mutation. Her father was not available for genetic studies.

Patient with p.Val182Ala mutation Clinical and laboratory data of the CDGP female patient with the p.Val182Ala mutation (patient 2) are shown in Table 3. At her first evaluation, she was 13 years old with a BA of 11 years and she had just started puberty. Her height was compromised (height SDS $=-2.5$ ) but her weight was normal (BMI SDS $=1.0$ ). She had IGF1 and IGFBP3 levels within the reference range, a normal GH peak after clonidine stimulation and LH, FSH, and estradiol levels within the prepubertal range. She had normal pubertal development, her menarche occurred at 14 years, and she achieved, without GH treatment, a normal final height of $154 \mathrm{~cm}(-1.4$ S.D.), but below her target height of $161.6 \mathrm{~cm}$ ( -0.1 s.D.). The patient's father and sister are also heterozygous for the GHSR mutation. Both of these individuals reported short stature during the prepubertal period as well as delayed puberty and reached normal adult height, a growth pattern compatible with CDGP. In addition, the sister of patient 2 was treated with recombinant human GH for GHD (maximum GH peak at stimulation test of $1.8 \mu \mathrm{g} / \mathrm{l}$ at the age of eleven), reaching a normal adult height of $155 \mathrm{~cm}(-1.2$ s.D. $)$.

\section{Discussion}

We report five new GHSR variations in patients with CDGP, all of them absent in a large ethnically matched population. Each amino acid substitution except for p.Ala358Thr occurred at a highly conserved position within the GHSR. Recent studies using whole-genomic

Table 2 Pharmacological properties of wild-type versus mutant GHSR. All values represent the mean \pm s.E.M. from at least five independent experiments.

\begin{tabular}{lccc}
\hline Receptor & Ghrelin pEC $_{\mathbf{5 0}}$ & $\begin{array}{c}\text { Basal } \\
\text { activity }^{\text {a }}\end{array}$ & $\begin{array}{c}\text { Surface } \\
\text { expression }\end{array}$ \\
\hline GHSR1a wt & $8.95 \pm 0.07$ & 100 & 100 \\
Val182Ala & $8.71 \pm 0.12$ & $52 \pm 3^{*}$ & $77 \pm 6^{*}$ \\
Ala169Thr & $8.70 \pm 0.16$ & $103 \pm 2$ & $81 \pm 6$ \\
Ala358Thr & $8.58 \pm 0.25$ & $88 \pm 4$ & $85 \pm 10$ \\
Ser84lle & $8.25 \pm 0.19^{*}$ & $3 \pm 1^{*}$ & $15 \pm 3^{*}$ \\
\hline
\end{tabular}

*Values differ significantly from the wild-type $(P<0.01)$.

apercentage of basal signaling activity of the wild-type GHSR.

bercentage of wild-type GHSR surface expression. 


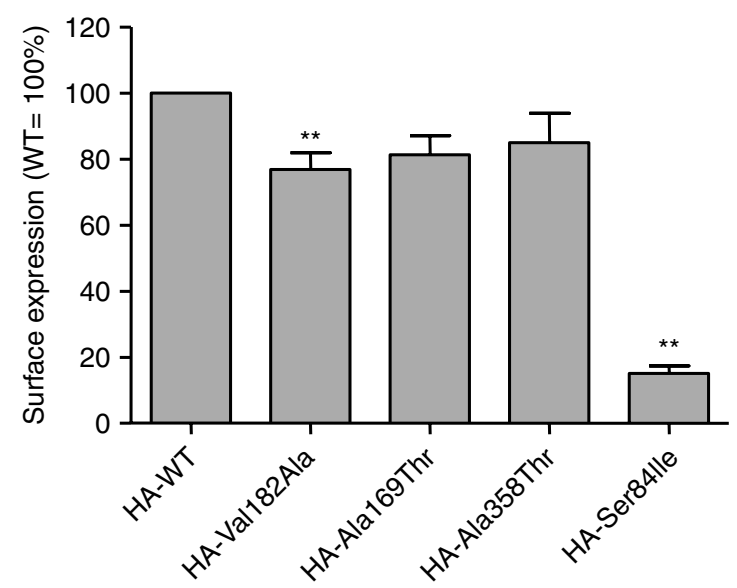

Figure 3 Selected GHSR variants show decreased cell surface expression. HEK293 cells were transfected with a plasmid encoding either the wild-type or a mutant HA-tagged GHSR. After $48 \mathrm{~h}$, surface expression was measured by ELISA as described in Patients and methods section. Data were normalized relative to the maximal value observed at the wild-type GHSR and represent the mean \pm S.E.M. from at least three independent experiments, each performed in triplicate. ${ }^{* \star} P<0.01$ expression level of GHSR mutant versus wild-type, ANOVA followed by Dunnett's post-test.

sequencing revealed that individuals tend to differ from a reference genome by putative loss of function mutations in 250-300 genes (28). However, focusing on GHSR, no loss-of-function variants were identified by low-coverage whole-genome sequencing of 179 individuals; an initial cohort from the 1000 genome project (http://browser.1000genomes.org/index.html) (28). Furthermore, the absence of other GHSR mutations in a large group of control children suggests that the association between GHSR variations and CDGP phenotype is unlikely to be fortuitous.

Functional studies confirmed the in silico prediction by PolyPhen and revealed that p.Ser84Ile and p.Val182Ala are functionally defective and will be designated as mutations. The mutations p.Ser84Ile and p.Val182Ala show a decrease in GHSR basal activity that is at least in part explained by a reduction in cell surface expression. The p.Ser84Ile variant was also associated with a decrease in ghrelin potency. As part of the molecular mechanism underlying the observed loss of function at these variants, it is possible that the mutations also directly or indirectly disrupt receptor coupling to intracellular signaling effectors, including the G-protein. These functional studies were performed in a heterologous cellular expression system. As previously documented for other GPCRs (29), it is possible that in the endogenous cellular microenvironment, the other identified variations might result in impaired GHSR function that is not evident when studied in HEK293 cells. However, it is most likely that the other variations (c. $-6 \mathrm{G}>\mathrm{C}$, p.Ala169Thr and p.Ala358Thr) are only rare benign polymorphisms.
The two mutations (p.Ser84Ile and p.Val182Ala) were found in the heterozygous state in two female patients with postnatal short stature during youth due to CDGP. GHD was excluded in both patients; however, IGF1 levels were at or below the lower normal limit of the reference values. Both patients had normal progression of puberty and spontaneously reached normal adult height. The p.Ser84Ile mutation was also found in members of the families that had neither the phenotype of short stature nor the delayed puberty, whereas the p.Val182Ala mutation segregated with CDGP phenotype in the family. These findings suggest a dominant mode of inheritance with incomplete penetrance, consistent with the pattern of inheritance observed in other families with $\operatorname{GHSR}$ mutations $(7,8)$ and in families with CDGP (30). Some possibilities to explain the incomplete penetrance and variable expression include interacting environmental factors and/or genetic variants at other loci.

CDGP is among the most commonly diagnosed growth disorders and it is considered a subcategory of ISS, as before the age of 13 years in girls or 14 years in

Table 3 Clinical and laboratorial characteristics of the two patients with functionally significant GHSR mutations.

\begin{tabular}{|c|c|c|}
\hline & Patient 1 & Patient 2 \\
\hline GHSR mutation & p.Ser84lle & p.Val182Ala \\
\hline Sex & Female & Female \\
\hline Father's height SDS & -1.5 & $+1.0^{\mathrm{a}}$ \\
\hline Mother's height SDS & +0.3 & -1.2 \\
\hline Target height in $\mathrm{cm}$ (SDS) & $158.1(-0.7)$ & $161.6(-0.1)$ \\
\hline Birth weight SDS & 1.0 & -0.9 \\
\hline Birth length SDS & -0.8 & -1.3 \\
\hline \multicolumn{3}{|l|}{ First evaluation } \\
\hline Age (years) & 12.8 & 13 \\
\hline Bone age (years) & 11 & 11 \\
\hline Height SDS & -2.4 & -2.3 \\
\hline BMI SDS & -2.6 & +1.1 \\
\hline \multicolumn{3}{|l|}{ Puberty } \\
\hline Aqe at start of puberty (years) & 13 & 13 \\
\hline Age at menarche (years) & 16 & 14 \\
\hline \multicolumn{3}{|l|}{ Last observation } \\
\hline Age (years) & 22 & 17.7 \\
\hline Height SDS & -0.8 & -1.4 \\
\hline $\mathrm{BMI}\left(\mathrm{kg} / \mathrm{m}^{2}\right)$ & 18.4 & 22.3 \\
\hline \multicolumn{3}{|l|}{ Laboratory evaluation } \\
\hline $\begin{array}{l}\text { GH peak at stimulation test } \\
(\mathrm{ng} / \mathrm{ml})\end{array}$ & 10.3 & 7.9 \\
\hline IGF1 SDS & $-2.3^{b} /-0.5^{c}$ & $-1.3^{\mathrm{b}}$ \\
\hline IGFBP3 SDS & $-1.6^{\mathrm{b}} /-2.2^{\mathrm{c}}$ & $+1.1^{\mathrm{b}}$ \\
\hline $\mathrm{LH}(\mathrm{UI} / \mathrm{I})$ & $<0.6^{\mathrm{b}} / 5.4^{\mathrm{c}}$ & $0.1^{\mathrm{b}}$ \\
\hline $\mathrm{FSH}(\mathrm{UI} / \mathrm{I})$ & $1.7^{b} / 6.4^{c}$ & $2.6^{\mathrm{b}}$ \\
\hline Estradiol (pg/ml) & $<13^{\mathrm{b} / 51^{\mathrm{c}}}$ & $13^{\mathrm{b}}$ \\
\hline Glucose (mg/dl) & $90^{\mathrm{C}}$ & $80^{\mathrm{b}}$ \\
\hline Insulin $(\mu \mathrm{U} / \mathrm{ml})$ & $7.7^{\mathrm{c}}$ & $10^{\mathrm{b}}$ \\
\hline Basal acylated ghrelin $(\mathrm{pg} / \mathrm{ml})^{\mathrm{d}}$ & $66.5^{c}$ & - \\
\hline After meal & & - \\
\hline Acylated ghrelin $(\mathrm{pg} / \mathrm{ml})^{d}$ & $53.1^{c}$ & - \\
\hline Suppression & $20 \%$ & _- \\
\hline
\end{tabular}

aPresence of the mutation in heterozygous state.

bSample collected at the first evaluation.

'Sample collected at the last evaluation.

${ }^{\mathrm{d}}$ Normal range for basal acylated ghrelin levels: $67.7 \pm 33.3 \mathrm{pg} / \mathrm{ml}$. 
boys, this condition cannot be differentiated from ISS (31). This disorder occurs more frequently in males $(18,32)$, and indeed, in our cohort, the proportion of males was greater in the CDGP group than in the non-CDGP group (77 vs $61 \%$, see Table 1 ). The fact that on the first evaluation our CDGP patients were older than the non-CDGP patients suggests that they might have reached a height SDS below -2.0 (short stature) later in life, therefore coming in later for medical evaluation. CDGP is characterized by a significant delay in both $\mathrm{BA}$ and adolescent growth spurt (31), which underlies the transient short stature stage, which is seen in affected individuals. Calculated measures of heritability suggest that $50-80 \%$ of the variance in pubertal onset is genetically controlled (30, 32). CDGP appears to be a multifactorial trait, yet at the same time the inheritance patterns suggests that single genes exert major effects (30). Although previous studies failed to identify mutations in candidate genes in patients with CDGP (33-38), the GHSR gene has not been previously investigated in patients with this condition (7-9). We regard our findings as hypothesis generating; it will be of great interest to screen other clinical cohorts with CDGP (as well as family members) to determine the frequency and inheritance pattern of GHSR mutations in various populations.

Ghrelin has orexigenic effects mediated by GHSR1a (4); therefore, it would be anticipated that mutations that impair ghrelin's receptor function would lead to a lean phenotype. In fact, animal studies showed that transgenic rats with attenuated GHSR protein expression in the arcuate nucleus have lower body weight, reduced adipose tissue, and consume less food than control rats (39). However, the patients with GHSR mutations described to date have a variable phenotype regarding weight (7-9). It was hypothesized that partial ghrelin system deficiency might be compensated by a host of developmental, genetic, and environmental factors that influence feeding behavior and body weight (8).

The exact mechanisms that trigger the start of puberty are yet unknown. Puberty onset is sensitive to the energy reserves of the organism, especially in females where there is an association between obesity and early puberty (reviewed in (40)). Therefore, we hypothesize that in the presence of GHSR mutations, there is a decrease in ghrelin-mediated appetite, resulting in relatively low BMI, which contributes to the delayed onset of puberty. Furthermore, delayed puberty is observed in clinical conditions associated with low IGF1 $(41,42)$, suggesting that IGF1 also exerts stimulatory, synergistic, or permissive effects on the onset of puberty (43). Thus, low IGF1 levels due to a decrease in GH secretion caused by GHSR 1a haploinsufficiency may also negatively modulate the timing of puberty onset.

In conclusion, this is the first report of GHSR mutations in patients with CDGP, a condition with a significant hereditary component, so far without a recognized genetic cause. Our study raises the intriguing possibility that there is an association between the observed GHSR mutations and the CDGP phenotype. Analyses of larger cohorts (including family members) are needed to explore the nature of this putative link. Such future efforts will better define the role of GHSR-mediated signaling on pubertal control.

\section{Declaration of interest}

The authors declare that there is no conflict of interest that could be perceived as prejudicing the impartiality of the research reported.

\section{Funding}

This study was supported by grants from Fundacao de Amparo a Pesquisa do Estado de Sao Paulo - FAPESP (09/00313-3), ConselhoNacional de Desenvolvimento Cientifico e Tecnologico - $\mathrm{CNPq}$ (143524/2008-9 to P N Pugliese-Pires, 300982/2009-7 to I J Arnhold and 301477/2009-4 to A A L Jorge), Fonds de la Recherche en Santé du Québec, the Canadian Institutes of Health Research (Fellowship Awards to J-P Fortin), and the National Institute of Diabetes and Digestive and Kidney Diseases (R01DK072497 to A S Kopin).

\section{References}

1 Howard AD, Feighner SD, Cully DF, Arena JP, Liberator PA, Rosenblum CI, Hamelin M, Hreniuk DL, Palyha OC, Anderson J, Paress PS, Diaz C, Chou M, Liu KK, McKee KK, Pong SS, Chaung LY, Elbrecht A, Dashkevicz M, Heavens R, Rigby M, Sirinathsinghji DJ, Dean DC, Melillo DG, Patchett AA, Nargund R, Griffin PR, DeMartino JA, Gupta SK, Schaeffer JM, Smith RG \& Van der Ploeg LH. A receptor in pituitary and hypothalamus that functions in growth hormone release. Science 1996273 974-977. (doi:10.1126/science.273.5277.974)

2 Holst B, Cygankiewicz A, Jensen TH, Ankersen M \& Schwartz TW. High constitutive signaling of the ghrelin receptor - identification of a potent inverse agonist. Molecular Endocrinology 200317 2201-2210. (doi:10.1210/me.2003-0069)

3 Kojima M, Hosoda H, Date Y, Nakazato M, Matsuo H \& Kangawa K. Ghrelin is a growth-hormone-releasing acylated peptide from stomach. Nature $1999 \mathbf{4 0 2} 656-660$. (doi:10.1038/45230)

4 Sun Y, Wang P, Zheng H \& Smith RG. Ghrelin stimulation of growth hormone release and appetite is mediated through the growth hormone secretagogue receptor. PNAS $2004 \mathbf{1 0 1}$ 4679-4684. (doi:10.1073/pnas.0305930101)

5 Yang J, Brown MS, Liang G, Grishin NV \& Goldstein JL. Identification of the acyltransferase that octanoylates ghrelin, an appetite-stimulating peptide hormone. Cell 2008132 387-396. (doi:10.1016/j.cell.2008.01.017)

6 Gutierrez JA, Solenberg PJ, Perkins DR, Willency JA, Knierman MD, Jin Z, Witcher DR, Luo S, Onyia JE \& Hale JE. Ghrelin octanoylation mediated by an orphan lipid transferase. PNAS 2008105 6320-6325. (doi:10.1073/pnas.0800708105)

7 Pantel J, Legendre M, Cabrol S, Hilal L, Hajaji Y, Morisset S, Nivot S, Vie-Luton MP, Grouselle D, de Kerdanet M, Kadiri A, Epelbaum J, Le Bouc Y \& Amselem S. Loss of constitutive activity of the growth hormone secretagogue receptor in familial short stature. Journal of Clinical Investigation 2006116 760-768. (doi:10.1172/JCI25303)

8 Pantel J, Legendre M, Nivot S, Morisset S, Vie-Luton MP, le Bouc Y, Epelbaum J \& Amselem S. Recessive isolated growth hormone deficiency and mutations in the ghrelin receptor. Journal of Clinical Endocrinology and Metabolism 200994 4334-4341. (doi:10. 1210/jc.2009-1327)

9 Wang HJ, Geller F, Dempfle A, Schauble N, Friedel S, Lichtner P, Fontenla-Horro F, Wudy S, Hagemann S, Gortner L, Huse K, Remschmidt H, Bettecken T, Meitinger T, Schafer H, Hebebrand J \& 
Hinney A. Ghrelin receptor gene: identification of several sequence variants in extremely obese children and adolescents, healthy normal-weight and underweight students, and children with short normal stature. Journal of Clinical Endocrinology and Metabolism 200489 157-162. (doi:10.1210/jc.2003-031395)

10 Inoue H, Kangawa N, Kinouchi A, Sakamoto Y, Kimura C, Horikawa R, Shigematsu Y, Itakura M, Ogata T \& Fujieda K. Identification and functional analysis of novel human growth hormone secretagogue receptor (GHSR) gene mutations in Japanese subjects with short stature. Journal of Clinical Endocrinology and Metabolism 201196 373-378. (doi:10.1210/jc.2010-1570)

11 Liu G, Fortin JP, Beinborn M \& Kopin AS. Four missense mutations in the ghrelin receptor result in distinct pharmacological abnormalities. Journal of Pharmacology and Experimental Therapeutics 2007322 1036-1043. (doi:10.1124/jpet.107.123141)

12 Holst B \& Schwartz TW. Ghrelin receptor mutations - too little height and too much hunger. Journal of Clinical Investigation 2006 116 637-641. (doi:10.1172/JCI27999)

13 Lango Allen H, Estrada K, Lettre G, Berndt SI, Weedon MN, Rivadeneira F, Willer CJ, Jackson AU, Vedantam S, Raychaudhuri S, Ferreira T, Wood AR, Weyant RJ, Segre AV, Speliotes EK, Wheeler E, Soranzo N, Park JH, Yang J, Gudbjartsson D, Heard-Costa NL, Randall JC, Qi L, Vernon Smith A, Magi R, Pastinen T, Liang L, Heid IM, Luan J, Thorleifsson G, Winkler TW, Goddard ME, Sin Lo K, Palmer C, Workalemahu T, Aulchenko YS, Johansson A, Zillikens MC, Feitosa MF, Esko T, Johnson T, Ketkar S, Kraft P, Mangino M, Prokopenko I, Absher D, Albrecht E, Ernst F, Glazer NL, Hayward C, Hottenga JJ, Jacobs KB, Knowles JW, Kutalik Z, Monda KL, Polasek O, Preuss M, Rayner NW, Robertson NR, Steinthorsdottir V, Tyrer JP, Voight BF, Wiklund F, Xu J, Hua Zhao J, Nyholt DR, Pellikka N, Perola M, Perry JR, Surakka I, Tammesoo ML, Altmaier EL, Amin N, Aspelund T, Bhangale T, Boucher G, Chasman DI, Chen C, Coin L, Cooper MN, Dixon AL, Gibson Q, Grundberg E, Hao K, Juhani Junttila M, Kaplan LM, Kettunen J, Konig IR, Kwan T, Lawrence RW, Levinson DF, Lorentzon M, McKnight B, Morris AP, Muller M, Suh Ngwa J, Purcell S, Rafelt S, Salem RM, Salvi E, Sanna S, Shi J, Sovio U, Thompson JR, Turchin MC, Vandenput L, Verlaan DJ, Vitart V, White CC, Ziegler A, Almgren P, Balmforth AJ, Campbell H, Citterio L, De Grandi A, Dominiczak A, Duan J, Elliott P, Elosua R, Eriksson JG, Freimer NB, Geus EJ, Glorioso N, Haiqing S, Hartikainen AL, Havulinna AS, Hicks AA, Hui J, Igl W, Illig T, Jula A, Kajantie E, Kilpelainen TO, Koiranen M, Kolcic I, Koskinen S, Kovacs P, Laitinen J, Liu J, Lokki ML, Marusic A, Maschio A, Meitinger T, Mulas A, Pare G, Parker AN, Peden JF, Petersmann A, Pichler I, Pietilainen KH, Pouta A, Ridderstrale M, Rotter JI, Sambrook JG, Sanders AR, Oliver Schmidt C, Sinisalo J, Smit JH, Stringham HM, Bragi Walters G, Widen E, Wild SH, Willemsen G, Zagato L, Zgaga L, Zitting P, Alavere H, Farrall M, McArdle WL, Nelis M, Peters MJ, Ripatti S, van Meurs JB, Aben KK, Ardlie KG, Beckmann JS, Beilby JP, Bergman RN, Bergmann S, Collins FS, Cusi D, den Heijer M, Eiriksdottir G, Gejman PV, Hall AS, Hamsten A, Huikuri HV, Iribarren C, Kahonen M, Kaprio J, Kathiresan S, Kiemeney L, Kocher T, Launer LJ, Lehtimaki T, Melander O, Mosley TH Jr, Musk AW, Nieminen MS, O'Donnell CJ, Ohlsson C, Oostra B, Palmer LJ, Raitakari O, Ridker PM, Rioux JD, Rissanen A, Rivolta C, Schunkert H, Shuldiner AR, Siscovick DS, Stumvoll M, Tonjes A, Tuomilehto J, van Ommen GJ, Viikari J, Heath AC, Martin NG, Montgomery GW, Province MA, Kayser M, Arnold AM, Atwood LD, Boerwinkle E, Chanock SJ, Deloukas P, Gieger C, Gronberg H, Hall P, Hattersley AT, Hengstenberg C, Hoffman W, Mark Lathrop G, Salomaa V, Schreiber S, Uda M, Waterworth D, Wright AF, Assimes TL, Barroso I, Hofman A, Mohlke KL, Boomsma DI, Caulfield MJ, Adrienne Cupples L, Erdmann J, Fox CS, Gudnason V, Gyllensten U, Harris TB, Hayes RB, Jarvelin MR, Mooser V, Munroe PB, Ouwehand WH, Penninx BW, Pramstaller PP, Quertermous T, Rudan I, Samani NJ, Spector TD, Volzke H, Watkins H, Wilson JF, Groop LC, Haritunians T, Hu FB, Kaplan RC, Metspalu A, North KE, Schlessinger D, Wareham NJ, Hunter DJ, O'Connell JR, Strachan DP, Wichmann HE, Borecki IB, van Duijn CM, Schadt EE, Thorsteinsdottir U, Peltonen L,
Uitterlinden AG, Visscher PM, Chatterjee N, Loos RJ, Boehnke M, McCarthy MI, Ingelsson E, Lindgren CM, Abecasis GR, Stefansson K, Frayling TM \& Hirschhorn JN. Hundreds of variants clustered in genomic loci and biological pathways affect human height. Nature 2010467 832-838. (doi:10.1038/nature09410)

14 Lanktree MB, Guo Y, Murtaza M, Glessner JT, Bailey SD, OnlandMoret NC, Lettre G, Ongen H, Rajagopalan R, Johnson T, Shen H, Nelson CP, Klopp N, Baumert J, Padmanabhan S, Pankratz N, Pankow JS, Shah S, Taylor K, Barnard J, Peters BJ, Maloney CM, Lobmeyer MT, Stanton A, Zafarmand MH, Romaine SP, Mehta A, van Iperen EP, Gong Y, Price TS, Smith EN, Kim CE, Li YR, Asselbergs FW, Atwood LD, Bailey KM, Bhatt D, Bauer F, Behr ER, Bhangale T, Boer JM, Boehm BO, Bradfield JP, Brown M, Braund PS, Burton PR, Carty C, Chandrupatla HR, Chen W, Connell J, Dalgeorgou C, Boer A, Drenos F, Elbers CC, Fang JC, Fox CS, Frackelton EC, Fuchs B, Furlong CE, Gibson Q, Gieger C, Goel A, Grobbee DE, Hastie C, Howard PJ, Huang GH, Johnson WC, Li Q, Kleber ME, Klein BE, Klein R, Kooperberg C, Ky B, Lacroix A, Lanken P, Lathrop M, Li M, Marshall V, Melander O, Mentch FD, Meyer NJ, Monda KL, Montpetit A, Murugesan G, Nakayama K, Nondahl D, Onipinla A, Rafelt S, Newhouse SJ, Otieno FG, Patel SR, Putt ME, Rodriguez S, Safa RN, Sawyer DB, Schreiner PJ, Simpson C, Sivapalaratnam S, Srinivasan SR, Suver C, Swergold G, Sweitzer NK, Thomas KA, Thorand B, Timpson NJ, Tischfield S, Tobin M, Tomaszweski M, Verschuren WM, Wallace C, Winkelmann B, Zhang H, Zheng D, Zhang L, Zmuda JM, Clarke R, Balmforth AJ, Danesh J, Day IN, Schork NJ, de Bakker PI, Delles C, Duggan D, Hingorani AD, Hirschhorn JN, Hofker MH, Humphries SE, Kivimaki M, Lawlor DA, Kottke-Marchant K, Mega JL, Mitchell BD, Morrow DA, Palmen J, Redline S, Shields DC, Shuldiner AR, Sleiman PM, Smith GD, Farrall M, Jamshidi Y, Christiani DC, Casas JP, Hall AS, Doevendans PA, Christie JD, Berenson GS, Murray SS, Illig T, Dorn GW II, Cappola TP, Boerwinkle E, Sever P, Rader DJ, Reilly MP, Caulfield M, Talmud PJ, Topol E, Engert JC, Wang K, Dominiczak A, Hamsten A, Curtis SP, Silverstein RL, Lange LA, Sabatine MS, Trip M, Saleheen D, Peden JF, Cruickshanks KJ, Marz W, O'Connell JR, Klungel OH, Wijmenga C, Maitland-van der Zee AH, Schadt EE, Johnson JA, Jarvik GP, Papanicolaou GJ, Grant SF, Munroe PB, North KE, Samani NJ, Koenig W, Gaunt TR, Anand SS, van der Schouw YT, Soranzo N, Fitzgerald GA, Reiner A, Hegele RA, Hakonarson H \& Keating BJ. Meta-analysis of dense genecentric association studies reveals common and uncommon variants associated with height. American Journal of Human Genetics 201188 6-18. (doi:10.1016/j.ajhg.2010.11.007)

15 Tanner JM, Whitehouse RH \& Takaishi M. Standards from birth to maturity for height, weight, height velocity, and weight velocity: British children, 1965. I. Archives of Disease in Childhood 196641 454-471. (doi:10.1136/adc.41.219.454)

16 Cohen P, Rogol AD, Deal CL, Saenger P, Reiter EO, Ross JL, Chernausek SD, Savage MO \& Wit JM. Consensus statement on the diagnosis and treatment of children with idiopathic short stature: a summary of the Growth Hormone Research Society, the Lawson Wilkins Pediatric Endocrine Society, and the European Society for Paediatric Endocrinology Workshop. Journal of Clinical Endocrinology and Metabolism 200893 4210-4217. (doi:10.1210/jc.2008-0509)

17 Silva EG, Slhessarenko N, Arnhold IJ, Batista MC, Estefan V, Osorio MG, Marui S \& Mendonca BB. GH values after clonidine stimulation measured by immunofluorometric assay in normal prepubertal children and GH-deficient patients. Hormone Research 200359 229-233. (doi:10.1159/000070222)

18 Sedlmeyer IL \& Palmert MR. Delayed puberty: analysis of a large case series from an academic center. Journal of Clinical Endocrinology and Metabolism 200287 1613-1620. (doi:10.1210/jc.87.4.1613)

19 Garcia EA, King P, Sidhu K, Ohgusu H, Walley A, Lecoeur C, Gueorguiev M, Khalaf S, Davies D, Grossman AB, Kojima M, Petersenn S, Froguel P \& Korbonits M. The role of ghrelin and ghrelin-receptor gene variants and promoter activity in type 2 diabetes. European Journal of Endocrinology 2009161 307-315. (doi:10.1530/EJE-09-0122) 
20 Reese MG, Eeckman FH, Kulp D \& Haussler D. Improved splice site detection in Genie. Journal of Computational Biology 19974 311-323. (doi:10.1089/cmb.1997.4.311)

21 Shapiro MB \& Senapathy P. RNA splice junctions of different classes of eukaryotes: sequence statistics and functional implications in gene expression. Nucleic Acids Research 198715 71557174. (doi:10.1093/nar/15.17.7155)

22 Ramensky V, Bork P \& Sunyaev S. Human non-synonymous SNPs: server and survey. Nucleic Acids Research $2002303894-3900$. (doi:10.1093/nar/gkf493)

23 Hearn MG, Ren Y, McBride EW, Reveillaud I, Beinborn M \& Kopin AS. A Drosophila dopamine 2-like receptor: molecular characterization and identification of multiple alternatively spliced variants. PNAS 200299 14554-14559. (doi:10.1073/pnas.202498299)

24 Beinborn M, Lee YM, McBride EW, Quinn SM \& Kopin AS. A single amino acid of the cholecystokinin-B/gastrin receptor determines specificity for non-peptide antagonists. Nature $1993 \mathbf{3 6 2}$ 348-350. (doi:10.1038/362348a0)

25 Blaker M, Ren Y, Gordon MC, Hsu JE, Beinborn M \& Kopin AS Mutations within the cholecystokinin-B/gastrin receptor ligand 'pocket' interconvert the functions of nonpeptide agonists and antagonists. Molecular Pharmacology 199854 857-863.

26 Al-Fulaij MA, Ren Y, Beinborn M \& Kopin AS. Identification of amino acid determinants of dopamine 2 receptor synthetic agonist function. Journal of Pharmacology and Experimental Therapeutics 2007321 298-307. (doi:10.1124/jpet.106.116384)

27 Fortin JP, Schroeder JC, Zhu Y, Beinborn M \& Kopin AS. Pharmacological characterization of human incretin receptor missense variants. Journal of Pharmacology and Experimental Therapeutics 2010332 274-280. (doi:10.1124/jpet.109.160531)

28 Durbin RM, Abecasis GR, Altshuler DL, Auton A, Brooks LD, Gibbs RA, Hurles ME \& McVean GA. A map of human genome variation from population-scale sequencing. Nature $2010 \mathbf{4 6 7}$ 1061-1073. (doi:10.1038/nature09534)

29 Oertel BG, Kettner M, Scholich K, Renne C, Roskam B, Geisslinger G, Schmidt PH \& Lotsch J. A common human microopioid receptor genetic variant diminishes the receptor signaling efficacy in brain regions processing the sensory information of pain. Journal of Biological Chemistry $2009 \mathbf{2 8 4} 6530-6535$. (doi:10.1074/jbc.M807030200)

30 Sedlmeyer IL, Hirschhorn JN \& Palmert MR. Pedigree analysis of constitutional delay of growth and maturation: determination of familial aggregation and inheritance patterns. Journal of Clinical Endocrinology and Metabolism $2002 \mathbf{8 7}$ 5581-5586. (doi:10. 1210/jc.2002-020862)

31 Wit JM, Clayton PE, Rogol AD, Savage MO, Saenger PH \& Cohen P. Idiopathic short stature: definition, epidemiology, and diagnostic evaluation. Growth Hormone and IGF Research 2008 18 89-110. (doi:10.1016/j.ghir.2007.11.004)

32 Wehkalampi K, Widen E, Laine T, Palotie A \& Dunkel L. Patterns of inheritance of constitutional delay of growth and puberty in families of adolescent girls and boys referred to specialist pediatric care. Journal of Clinical Endocrinology and Metabolism 200893 723-728. (doi:10.1210/jc.2007-1786)

33 Banerjee I, Trueman JA, Hall CM, Price DA, Patel L, Whatmore AJ, Hirschhorn JN, Read AP, Palmert MR \& Clayton PE. Phenotypic variation in constitutional delay of growth and puberty: relationship to specific leptin and leptin receptor gene polymorphisms. European Journal of Endocrinology $2006 \quad 155$ 121-126. (doi:10.1530/eje.1.02184)
34 Banerjee I, Hanson D, Perveen R, Whatmore A, Black GC \& Clayton PE. Constitutional delay of growth and puberty is not commonly associated with mutations in the acid labile subunit gene. European Journal of Endocrinology $2008 \mathbf{1 5 8} 473-477$. (doi:10.1530/EJE-07-0769)

35 Tommiska J, Wehkalampi K, Vaaralahti K, Laitinen EM, Raivio T \& Dunkel L. LIN28B in constitutional delay of growth and puberty. Journal of Clinical Endocrinology and Metabolism $2010 \mathbf{9 5}$ 3063-3066. (doi:10.1210/jc.2009-2344)

36 Teles MG, Trarbach EB, Noel SD, Guerra-Junior G, Jorge A, Beneduzzi D, Bianco SD, Mukherjee A, Baptista MT, Costa EM, De Castro M, Mendonca BB, Kaiser UB \& Latronico AC. A novel homozygous splice acceptor site mutation of KISS1R in two siblings with normosmic isolated hypogonadotropic hypogonadism. European Journal of Endocrinology 2010163 29-34. (doi:10. 1530/EJE-10-0012)

37 Sedlmeyer IL, Pearce CL, Trueman JA, Butler JL, Bersaglieri T, Read AP, Clayton PE, Kolonel LN, Henderson BE, Hirschhorn JN \& Palmert MR. Determination of sequence variation and haplotype structure for the gonadotropin-releasing hormone $(\mathrm{GnRH})$ and GnRH receptor genes: investigation of role in pubertal timing. Journal of Clinical Endocrinology and Metabolism 200590 1091-1099. (doi:10.1210/jc.2004-0649)

38 Semple RK, Achermann JC, Ellery J, Farooqi IS, Karet FE, Stanhope RG, O'Rahilly S \& Aparicio SA. Two novel missense mutations in $\mathrm{G}$ protein-coupled receptor 54 in a patient with hypogonadotropic hypogonadism. Journal of Clinical Endocrinology and Metabolism 2005 90 1849-1855. (doi:10.1210/jc.2004-1418)

39 Shuto Y, Shibasaki T, Otagiri A, Kuriyama H, Ohata H, Tamura H, Kamegai J, Sugihara H, Oikawa S \& Wakabayashi I. Hypothalamic growth hormone secretagogue receptor regulates growth hormone secretion, feeding, and adiposity. Journal of Clinical Investigation 2002109 1429-1436. (doi:10.1172/ JCI200213300)

40 Kaplowitz PB. Link between body fat and the timing of puberty. Pediatrics 2008121 (Supplement 3) S208-S217. (doi:10.1542/ peds.2007-1813F)

41 Pugliese-Pires PN, Tonelli CA, Dora JM, Silva PC, Czepielewski M, Simoni G, Arnhold IJ \& Jorge AA. A novel STAT5B mutation causing GH insensitivity syndrome associated with hyperprolactinemia and immune dysfunction in two male siblings. European Journal of Endocrinology 2010163 349-355. (doi:10.1530/EJE10-0272)

42 Fofanova-Gambetti OV, Hwa V, Wit JM, Domene HM, Argente J, Bang P, Hogler W, Kirsch S, Pihoker C, Chiu HK, Cohen L, Jacobsen C, Jasper HG, Haeusler G, Campos-Barros A, GallegoGomez E, Gracia-Bouthelier R, van Duyvenvoorde HA, Pozo J \& Rosenfeld RG. Impact of heterozygosity for acid-labile subunit (IGFALS) gene mutations on stature: results from the international acid-labile subunit consortium. Journal of Clinical Endocrinology and Metabolism 2010 95 4184-4191. (doi:10.1210/jc.2010-0489)

43 Chandrashekar V, Zaczek D \& Bartke A. The consequences of altered somatotropic system on reproduction. Biology of Reproduction 2004 71 17-27. (doi:10.1095/biolreprod.103.027060)

Received 1 May 2011

Accepted 6 June 2011 